\section{Origin of Species}

\section{Premises, premises}

Origin of Species is the latest in the series of new permanent exhibitions scheduled by the British Museum (Natural History). Under any circumstances, it would be an important exhibition, lying at the heart of what the museum is trying to explain. Unless there is some central thread of theory linking together louse and lousewort, Archaeopteryx and albatross, bushbaby and bushman, the exhibits that surround us in the museum are of no greater significance than a collection of postage stamps - interesting for their variety, occasionally beautiful, but intellectually sterile. But circumstances today make us look even more closely at such an exhibition, for evolutionary theory seems to be assailed ever more fiercely by its enemies, and to be only half-heartedly defended by its supporters.

Let's start, though, with the presentation and packaging, which is what will (or will not) attract the visitor in the first place. The Origin of Species exhibition is mounted in the western wing of the premises designed by Waterhouse. Spacious, elegant and well-windowed, it is a beautiful foil for the exhibition, which is arranged in eleven sections, each presenting a different aspect of the theory of evolution by natural selection: the species, competition, variation, inheritance and so on. With the inevitable few minor reservations, I thought that this system worked very well: each concept is comprehensible and is clearly and attractively explained. Both diagrammatic and real-life presentations are used, and are cleverly intermingled. There is also a natural selection computer game, designed to appeal to the Space Invaders generation. Finally, there are four mini-theatres in which film-loops explain different aspects of the theory.

Understanding the details of Darwin's theory is, however, only one part of what we scientists hope our museums will do for us. In the face of the organized pressures of religious and mystical sects, evolutionists need some organization to represent their views, no less fervently held, as cogently as possible. Not that it should descend to the half-truths and double-talk of political propaganda. But it should suit the terms of its message to those who will listen to it, rather than blunting its edge with the hairsplitting logic-chopping of the philosophy of science. Here, I fear, the BM $(\mathrm{NH})$ has failed us.

"The Survival of the Fittest is an empty phrase; it is a play on words. For this reason, many critics feel that not only is the idea of evolution unscientific, but the idea of natural selection also. There's no point in asking whether or not we should believe in the idea of natural selection, because it is the inevitable logical consequence of a set of premises." "The idea of evolution by natural selection is a matter of logic, not science, and it follows that the concept of evolution by natural selection is not, strictly speaking, scientific." "If we accept that evolution has taken place, though obviously we must keep an open mind on it ." "We can't prove that the idea is true, only that it has not yet been proved false." "It may one day be replaced by a better theory, but until then . . . ." These are all quotations from the film loop in which the present status of the theory of evolution is explained to a layman by a scientist. If this is the voice of our friends and supporters, then Creation protect us from our enemies.

Of course, to a scientist, evolution and natural selection are "only" theories but how much real doubt is implied by that statement? The philosopher of science may utter his customary caution "Anything you say will be taken down; it will only be falsifiable, and can never be proved true"'. But these theories have withstood over a century of testing, by a great variety of methods unimaginable to Darwin. These methods not only all support a theory of evolution in general fashion, they combine to support a single, precise version of the relationships of living things. For example, palaeontology, biogeography, serology, protein sequencing etcetera, all suggest that man is most closely related to the African apes, rather than each type of evidence pointing to a different branch of the tree of life. The significance of Mendel's work was not merely that it did not support Lamarck (as the film-loop tells us), but also that it was exactly what Darwin's theory demanded and had, to that extent, effectively predicted (which the film-loop does not tell us). How many biologists really think that, one day, they will open Nature and find a new, completely different theory of evolution?

Equally, if we say that Darwin's theory may one day be replaced by a "better theory', do we really mean anything completely different? In fact, of course, few biologists consider it remotely possible that the great variety of evidence that supports this theory could suddenly be rearranged to provide an even more persuasive support for a creationist theory. But that is not all. We don't even think that it could support a dramatically different scientific theory, in the way that earlier observations of the heavens were transformed from being compatible with an Earth-centred Universe to demonstrating a Sun-centred Solar System. Genetic drift or neo-Lamarckism may lead to changes of emphasis or provide explanations of the exceptional or the rare, but they show no signs whatever of taking over the central ground of our science. Though no biologist can deny the possibility that God created man, few

\section{Huxley on Nature}

At the celebrations of the centenary of the move of the British Museum (Natural History) to the building it now occupies in South Kensington (London), the president of the Royal Society, Sir Andrew Huxley, devoted the major part of his speech to an attack on Nature for giving publicity to criticism of the museum (of which Sir Andrew is now a trustee) in recent months.

Sir Andrew complained that Nature has "printed more than 30 letters centering around attacks on the scientific thinking of members of staff of the museum" and said that the correspondence, especially that relating to cladistics, would have been "unintelligible to 99 per cent of the readership of Nature".

The "obscurities and irrelevances" of the debate were "in cloud-cuckoo land". Sir Andrew said that Nature published such letters for the same reason that The Times of London devoted "so much space to the Sutcliffe trial" (a recent sensational murder trial in Britain) "their readers enjoy these things".

Sir Andrew also accuses Nature of having published a leading article about the museum "on the basis of a few words" taken out of context, and of not having published "a brief reply from the museum". Sir Andrew warned Nature that "crying wolf will drive its readers into disregarding its future warnings" and those "wounded by these articles" should ignore them.

would doubt that, if $\mathrm{He}$ did so, the mechanism that Darwin discerned was the one that He chose to use. It is the strength of conviction of working biologists that needs to be accurately translated to the man in the museum gallery, not the technical caveats with which we remind ourselves of the potential weaknesses of more recent or less wide-ranging theories. And let us not forget that Dr Roger Miles, head of the museum's Public Services Department, is quoted as saying that their exhibitions are aimed at the average 15 -year-old, not at scholars.

Lest I be accused of losing my sense of proportion, let me repeat that I found most of the exhibition appealing, satisfying and clear. If I take issue at length with one small part of it, it is because I consider that part to be crucial. This film-loop will be studied primarily by those few people who are really interested in trying to find out precisely how the world of science views this most important and wide-ranging explanation of the phenomena of the living world, and they may judge this against the less dispassionate appeals of such groups as the creationists. Just as war may be too serious to be left to the military, so the presentation of science is too crucial to the scientist to be left wholly at the mercy of the populist presenter.

Barry Cox 